\title{
Study of Parameter Optimization Vanadium Steel U sing Taguchi Technique
}

\author{
Sayed Imran ${ }^{1}$, Satish Kumar ${ }^{2}$ \\ ${ }^{1}$ M.Tech Scholar, Department of Mechanical Engineering, HCTM Technical Campus, Kaithal, Haryana, India \\ ${ }^{2}$ Assistant Professor, Department of Mechanical Engineering, HCTM Technical Campus, Kaithal, Haryana, India
}

\begin{abstract}
The aim of the present study is to show the influence of different input parameters such as machining, surface finish \& mec hanical properties during the turning Process of Vanadium steel. The microstructure, hardness and tensile strength of Vanadium steel a re investigated in this study. The selected three input parameters were varied at three levels. On the analogy, nine experiments were perfo rmed based on L9 orthogonal array of Taguchi's methodology, which consist three input parameters. Analysis of variance (ANOVA) wa $s$ employed to find the levels of significance of input parameters.
\end{abstract}

Keywords: Turning, Vanadium Steel, ANOVA, Taguchi

\section{Introduction}

Turning is a method that can be used to remove unwanted material from steel in order to get its required shape and size. Turning process is defined as machining of steel with hardness greater than $207 \mathrm{BHN}$. The temperature generated during turning is substantially higher when compared to conventional machining. Turning is a machining process to produce parts round in shape by a single point tool on lathes. The tool is fed either linearly in the direction parallel or perpendicular to the axis of rotation of the work piece, or along a specified path to produce complex rotational shapes. The primary motion of cutting in turning is the rotation of the work piece, and the secondary motion of cutting is the feed motion.

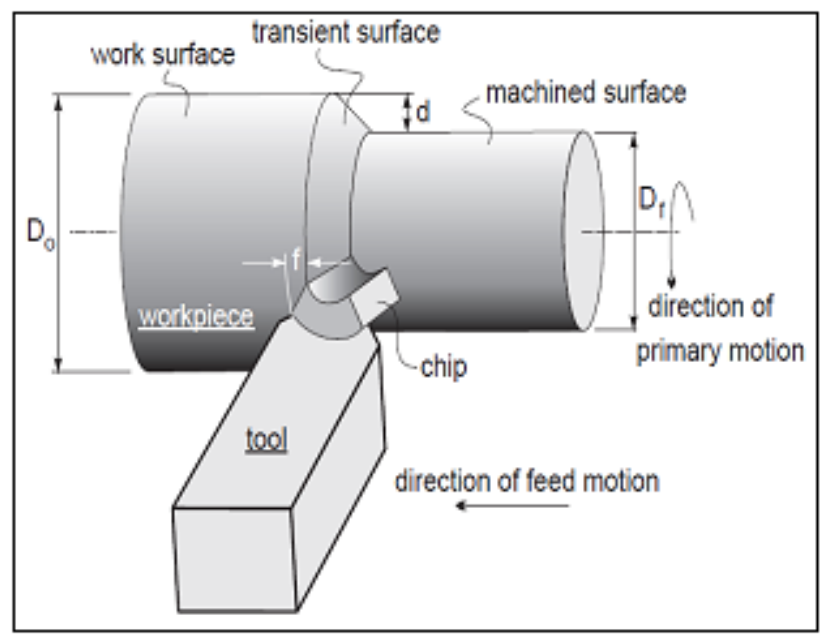

Figure 1.1: Turning Operations

\subsection{Background}

Turning has emerged as a viable alternative to grinding for fi nish machining of steels. Steel is widely used in manufacturi ng components such as gear, bearing, tools and die (Kalpakji an and Schmid, 2006). Its properties of high wear resistance, good corrosion resistance and high surface finish have result ed in this material to be used in producing the components $\mathrm{m}$ entioned. Hard turning is performed on materials with hardne ss within the 45-68 Rockwell Hardness range using a variety of tipped or solid cutting inserts. Although grinding is know $\mathrm{n}$ to produce good surface finish at relatively high feed rates, hard turning can produce as good or better surface finish at si gnificantly higher material removal rates (Huddle D., 2001). Grinding has traditionally been used to finish machine harde ned steel. The technique has some limitations: it is time cons uming and only limited range of geometries can be produced. The development of advanced cutting tool materials has led to the improvement in the cutting process of hardened steel. Studies have shown that using the right combination of insert nose radii, feed rate or the new insert technology, hard turni ng can produce better surface finish and less tool wear than $g$ rinding.

\subsection{Cutting Conditions in Turning}

Cutting speed in turning $\mathrm{V}$ in $\mathrm{m} / \mathrm{s}$ is related to the rotational $\mathrm{s}$ peed of the workpiece by the equation:

$$
\mathrm{V}=\pi \mathrm{DN}
$$

Where $\mathrm{D}$ is the diameter of the workpiece, $\mathrm{m}$; $\mathrm{N}$ is the rotatio nal speed of the workpiece, rev/s.

One should remember that cutting speed V is always a linear vector. In the process planning of a turning operation, cutting speed V is first selected from appropriate reference sources or calculated as discussed in Section 5.10 Selection of Cuttin $\mathrm{g}$ Conditions, and the rotational speed $\mathrm{N}$ is calculated taking into account the workpiece diameter D. Rotational speed, not cutting speed, is then used to adjust lathe setting levers.

Feed in turning is generally expressed in mm tr-1 (millimetre $\mathrm{s}$ per revolution).

The turning operation reduces the diameter of the workpiece from the initial diameter Do to the final diameter Df. The cha nge in diameter is actually two times depth of cut, $d$ :

$$
\text { 2d = Do - Df }
$$

The volumetric rate of material removal (so-called material $r$ emoval rate, mrr) is defined by 


\section{$\operatorname{mrr}=\mathbf{V f d}$}

When using this equation, care must be exercised to assure th at the units for $\mathrm{V}$ are consistent with those for $\mathrm{f}$ and $\mathrm{d}$.

\section{Literature Review}

In this chapter, review of relevant literature explaining vario us factors affecting, material removal rate, surface roughness during finish hard turning has been made. The salient featur es of the most relevant research works are reported in the foll owing text.

Patel et al [2014] explains in his paper that Alloy Steel has a wide variety of applications in different industries. The Chal lenge of modern machining industries is mainly focused on a chieving high quality, in term of part/component accuracy, s urface finish, high production rate and increase the product li fe with lesser environmental impact. It is necessary to change and improve existing technology and develop product with $r$ easonably priced. So, it is necessary control the process para meter in any manufacturing process. The typical controllable machining parameters for the CNC lathe machines are speed , feed, depth of cut, tool geometry, cutting environment, tool material, work material, etc. which affect desired output like material removal rate, surface roughness, power consumptio $\mathrm{n}$, tool wear, vibration etc. Optimization of machining param eters and also need to determine which parameters are most $\mathrm{s}$ ignificant for required output. One of the techniques widely $u$ sed for optimization of machining parameters is Taguchi and ANOVA approach help to determine which parameters are most significant.

Quazi et al [2014] study various techniques for the optimizat ion for that purpose literature review and industrial survey is conducted. The objective of this study was to utilize Taguchi methods to optimize surface roughness in turning mild steel, EN-8 and EN-31. The turning parameters evaluated are cutti ng speed of 200,250 , and $300 \mathrm{~m} / \mathrm{min}$, feed rate of $0.08,0.12$ and $0.15 \mathrm{~mm} / \mathrm{rev}$, depth of cut of $0.5 \mathrm{~mm}$ and tool grades of TN60, TP0500 and TT8020, each at three levels. The experi ment was designed and carried out on the basis of standard $\mathrm{L}$ 9 Taguchi orthogonal array. The results show that the Taguc hi method is suitable to solve the stated problem with minim um number of trials as compared with full factorial design.

Kumar et al [2013] states that many manufacturing industri es involve machining operations. In metal cutting the turning process is one of the most fundamental cutting processes use d. Surface finish and dimensional tolerance, are used to deter mine and evaluate the quality of a product, and are major qua lity attributes of a turned product. In this paper experimental work has been carried out for the optimization of input para meters for the improvement of quality of the product of turni ng operation on CNC machine. Feed Rate, Spindle speed \& d epth of cut are taken as the input parameters and the dimensi onal tolerances as output parameter. In the present work L9 Array has been used in design of experiment for optimization of input parameters. This paper attempts to introduce and th us verifies experimentally as to how the Taguchi parameter $\mathrm{d}$ esign could be used in identifying the significant processing parameters and optimizing the surface roughness in the turni ng operation. The present work shows that spindle speed is $\mathrm{t}$ he key factor for minimizing the dimensional variation for $\mathrm{m}$ inimizing the surface roughness.

Korat et al [2012] outlines an experimental study to optimi ze the effects of cutting parameters on surface finish and MR $\mathrm{R}$ of EN24/AISI43 work material by employing Taguchi tech niques.

The orthogonal array, signal to noise ratio and analysis of var iance were employed to study the performance characteristic $\mathrm{s}$ in turning operation. Five parameters were chosen as proce ss variables: Speed, Feed, Depth of cut, Nose radius, Cutting environment (wet and dry). The experimentation plan is desi gned using Taguchi's L18 Orthogonal Array (OA) and Minit ab 16 statistical software is used. Optimal cutting parameters for, minimum surface roughness (SR) and maximum materia 1 removal rate were obtained. Thus, it is possible to increase machine utilization and decrease production cost in an autom ated manufacturing environment

\section{Methodology}

The work piece material was Vanadium steel shown as in Fig ure 3.1. Vanadium steel is a high carbon Alloy steel which ac hieves a high degree of hardness with compressive strength a nd abrasion resistance. By its character this type of steel has high resisting nature against wear and can be used for compo nents which are subjected to severe abrasion, wear or high su rface loading.

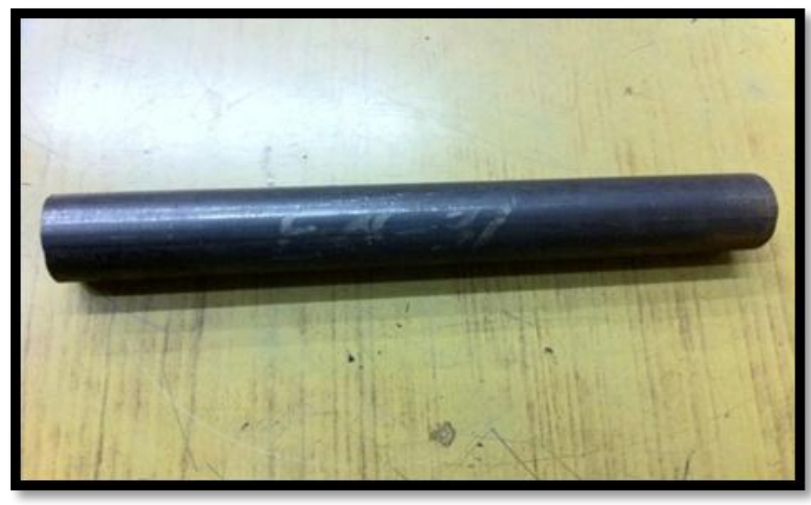

Figure 3.1: Material: Vanadium steel

\subsection{Statistics of the use of vanadium}

The world consumption of vanadium is today (1999)some 3 4000tonnes per annum, of which 28000tonnes in the Wester n world.

The predominant application of vanadium is for alloying of steel and cast iron. It amounts to about $85 \%$ of the total co nsumption, a share that appears rather stable over time. The remaining part goes to chemicals and to alloying of tita nium. World-wide about $65 \%$ of the vanadium for alloying of steel is used in micro alloyed structural steels, whereas th e remaining 35\% is used in V-alloyed steels, such as high speed and tools steels, high temperature low alloy steel, etc.

Table 1: Composition of alloying element in Vanadium steel

\begin{tabular}{|c|c|c|c|c|c|c|}
\hline $\mathrm{C} \%$ & $\mathrm{Si} \%$ & $\mathrm{Mn} \%$ & $\mathrm{~S} \%$ & $\mathrm{P} \%$ & $\mathrm{Ni} \%$ & $\mathrm{Cr} \%$ \\
\hline 0.20 & 0.29 & 1.49 & 0.014 & 0.035 & 0.043 & 0.126 \\
\hline
\end{tabular}

\section{Volume 6 Issue 7, July 2017 www.ijsr.net}




\section{International Journal of Science and Research (IJSR) \\ ISSN (Online): 2319-7064}

Index Copernicus Value (2015): 78.96 | Impact Factor (2015): 6.391

\begin{tabular}{|c|c|c|c|c|c|c|}
\hline $\mathrm{Mo} \%$ & $\mathrm{~V} \%$ & $\mathrm{Cu} \%$ & $\mathrm{Al} \%$ & $\mathrm{~B} \%$ & $\mathrm{~Pb} \%$ & $\mathrm{Fe} \%$ \\
\hline 0.018 & 0.106 & 0.084 & 0.023 & 0.0005 & $<0.0005$ & 97.5 \\
\hline
\end{tabular}

\subsection{Surface Roughness Analyzer}

A Mitutoyo Surftest SJ-301 Portable Surface Roughness Test er was used to measure the roughness profile data after each cut. Specifications are given below:

- Make

Mitutoyo, Japan

- Model

SurfTest SJ-301

- Measurement range $200 \mu \mathrm{m}$ to $+250 \mu \mathrm{m}$

- Stylus material Diamond

- Tip radius $2 \mu \mathrm{m} / 5 \mu \mathrm{m}$

- Measuring force $4 \mathrm{mN}(0.4 \mathrm{gf})$

- Cut-off length $0.8 \mathrm{~mm}-2.5 \mathrm{~mm}$

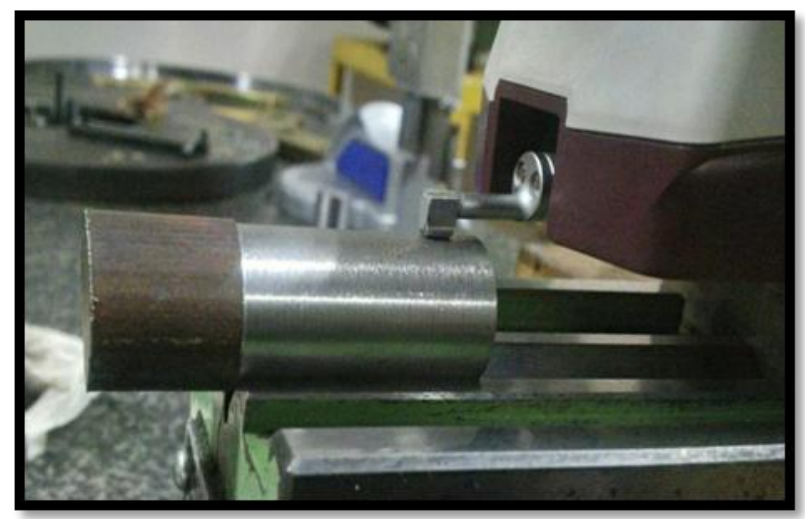

Figure 3.2: Mitutoyo Surface Roughness tester

\section{Experimental Plan}

In this experiment, Taguchi OA Design $\mathrm{L}_{9}$ was used to desig $\mathrm{n}$ the experimental plan. Cutting speed, feed rate and depth o f cut were varied in this experiment.

Table 2: Cutting condition for the experiment

\begin{tabular}{|c|c|c|c|c|}
\hline Cutting parameter & Unit & Level 1 & Level 2 & Level 3 \\
\hline Cutting speed & $\mathrm{m} / \mathrm{min}$ & 120 & 140 & 160 \\
\hline Feed rate & $\mathrm{mm} / \mathrm{rev}$ & 0.05 & 0.10 & 0.15 \\
\hline Depth of cut & $\mathrm{mm}$ & 0.1 & 0.2 & 0.3 \\
\hline
\end{tabular}

The concept of Design of Experiment was first introduced in early 1920 in a small station of Agricultural Research in Engl and, by a scientist called Sir. Ronald Fisher. He showed that a valid experiment could be conducted in the presence of ma ny natural conditions variables, such as: temperature, soil co nditions and rainfall. The principles of experimental design fi rst used in agriculture have been adapted successfully in indu stry and in military applications since 1940 (Franceschini an d Macchietto, 2008).

Montgomery (1997) states that before starting the experimen tation it is important to establish the planning of experiments. He emphasized the importance of the problem domain by all those involved in the experiment, and recommended that dur ing the implementation process is carefully monitored to ens ure that everything be done according to plan.

The DOE is a technique used to define what data, in what qu antity and conditions should be collected during an experime nt, trying to satisfy two major goals: the statistical accuracy o $\mathrm{f}$ the response and lower cost (Gunasegaram et al., 2009).

\subsection{Procedure to determine the appropriate Orthogonal}

\section{Array (OA)}

1) Define the number of factors and their levels.

2) Determine the degrees of freedom.

3) Select an orthogonal array.

4) Consider any interactions.

5) Degree of freedom of orthogonal array is always greater than degree of freedom of factors and interactions.

For this case the Orthogonal Array of $\mathrm{L}(\mathrm{OA})_{9}(3)^{3}$ has been $\mathrm{s}$ elected.

Where,

9 means number of trials

(3) Means number of levels of each factor

( ) ${ }^{3}$ means number of factors.

L, Orthogonal Array- (3) ${ }^{3}$ for Surface Roughness (Ra) an d Material Removal Rate

Table 3: Taguchi's recommended orthogonal array design

\begin{tabular}{|c|c|c|c|}
\hline $\begin{array}{c}\text { Experiment Speed Feed } \\
\text { D.O.C }\end{array}$ & A & B & C \\
\hline 1 & 1 & 1 & 1 \\
\hline 2 & 1 & 2 & 2 \\
\hline 3 & 1 & 3 & 3 \\
\hline 4 & 2 & 1 & 2 \\
\hline 5 & 2 & 2 & 3 \\
\hline 6 & 2 & 3 & 1 \\
\hline 7 & 3 & 1 & 3 \\
\hline 8 & 3 & 2 & 1 \\
\hline 9 & 3 & 3 & 2 \\
\hline
\end{tabular}

Experimental Orthogonal Array $-\mathrm{L}_{9}$ OA (3) ${ }^{3}$ forSurface Roughness (Ra) and Material Removal rate

Table 4: Experimental orthogonal array

\begin{tabular}{|c|c|c|c|}
\hline \multirow{2}{*}{ Experiment } & A & B & C \\
\cline { 2 - 4 } & Speed & Feed & D.O.C \\
\hline 1 & 120 & 0.05 & 0.1 \\
\hline 2 & 120 & 0.10 & 0.2 \\
\hline 3 & 120 & 0.15 & 0.3 \\
\hline 4 & 140 & 0.05 & 0.2 \\
\hline 5 & 140 & 0.10 & 0.3 \\
\hline 6 & 140 & 0.15 & 0.1 \\
\hline 7 & 160 & 0.05 & 0.3 \\
\hline 8 & 160 & 0.10 & 0.1 \\
\hline 9 & 160 & 0.15 & 0.2 \\
\hline
\end{tabular}

Response Parameters for orthogonal array- OA L9 (3) ${ }^{3}$ S urface Roughness (Ra) and Material Removal rate.

Table 5: Response Ra and MRR

\begin{tabular}{|c|c|c|c|c|c|}
\hline \multirow{2}{*}{ Experiment } & A & B & C & & \\
\cline { 2 - 6 } & Speed & Feed & D.O.C & Ra & MRR \\
\hline 1 & 120 & 0.05 & 0.1 & 4.90 & 5.29 \\
\hline 2 & 120 & 0.10 & 0.2 & 5.50 & 4.87 \\
\hline 3 & 120 & 0.15 & 0.3 & 5.70 & 4.61 \\
\hline 4 & 140 & 0.05 & 0.2 & 7.75 & 7.89 \\
\hline 5 & 140 & 0.10 & 0.3 & 6.32 & 5.70 \\
\hline 6 & 140 & 0.15 & 0.1 & 6.80 & 6.83 \\
\hline 7 & 160 & 0.05 & 0.3 & 5.45 & 6.15 \\
\hline 8 & 160 & 0.10 & 0.1 & 4.50 & 6.10 \\
\hline 9 & 160 & 0.15 & 0.2 & 7.29 & 7.50 \\
\hline
\end{tabular}




\section{International Journal of Science and Research (IJSR) \\ ISSN (Online): 2319-7064 \\ Index Copernicus Value (2015): 78.96 | Impact Factor (2015): 6.391}

\section{Result and Discussion}

The main effects can be studied by the level average respons e analysis of raw data or of $\mathrm{S} / \mathrm{N}$ data. The analysis is done by averaging the raw or $\mathrm{S} / \mathrm{N}$ data at each level of each paramete $r$ and plotting the values in graphical form. The level average responses from the raw data help in analyzing the trend of th e performance characteristics with respect to the variation of the factor under study. The level average response plots base $\mathrm{d}$ on the $\mathrm{S} / \mathrm{N}$ data help in optimizing the objective function $\mathrm{u}$ nder consideration. The lower points of these plots correspon $\mathrm{d}$ to the optimum condition for average surface roughness.

\begin{tabular}{|l|}
\hline Step-1 Select the quality characteristics \\
\hline Step-2 Select Noise and control Factors \\
\hline Step-3 Select Taguchi Orthogonal Array \\
\hline \multicolumn{2}{|c|}{ Step-4 Conduct the Experiments } \\
\hline Step-5 Analyze Result (S/N Ratio, ANOVA) \\
\begin{tabular}{|l|}
\hline Step-6 Predict Optimum Performance \\
\hline Step-7 Confirmation Experiments \\
\hline
\end{tabular} \\
\hline
\end{tabular}

Analysis of variance (ANOVA) is performed and signal-to-n oise $(\mathrm{S} / \mathrm{N})$ ratio will be determined to know the level of impo rtance of the machining parameters. To obtain the optimal $\mathrm{m}$ achining performance the higher the better quality characteri stics for Surface Roughness and MRR. As can be seen from Table (above), the MRR is most significantly influenced by $t$ he feed followed by the Depth of cut. The respective values o $\mathrm{f}$ these parameters are 1.71 and 2.11 . S/N ratio are calculated and graph for analysis is drawn by using Minitab 16 software . The S/N ratio for MRR is calculated on Minitab 16 Softwar e using Taguchi Method.

The greater average $\mathrm{S} / \mathrm{N}$ ratio corresponds to the max MRR. From the $\mathrm{S} / \mathrm{N}$ response table 5.5 , it is concluded that the opti mumparametric combination is Speed (140), Feed (0.15), an $\mathrm{d}$ depth of cut (0.2). In other words, it is this combination of parametersthat gives the max MRR for the machined materia 1.

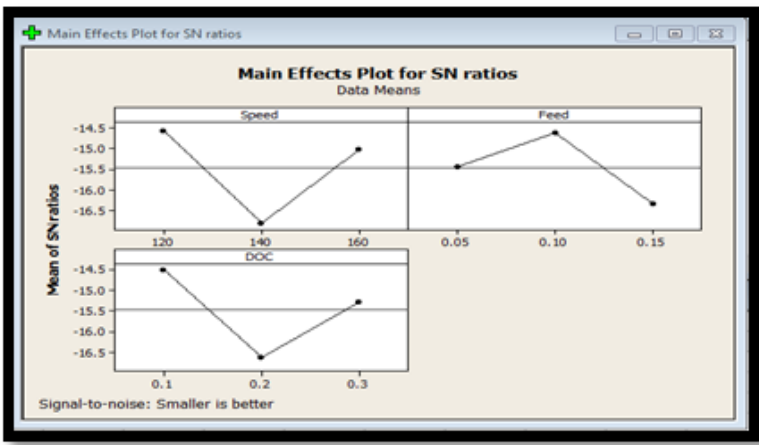

Figure 4.1: S/N graph for Surface Roughness

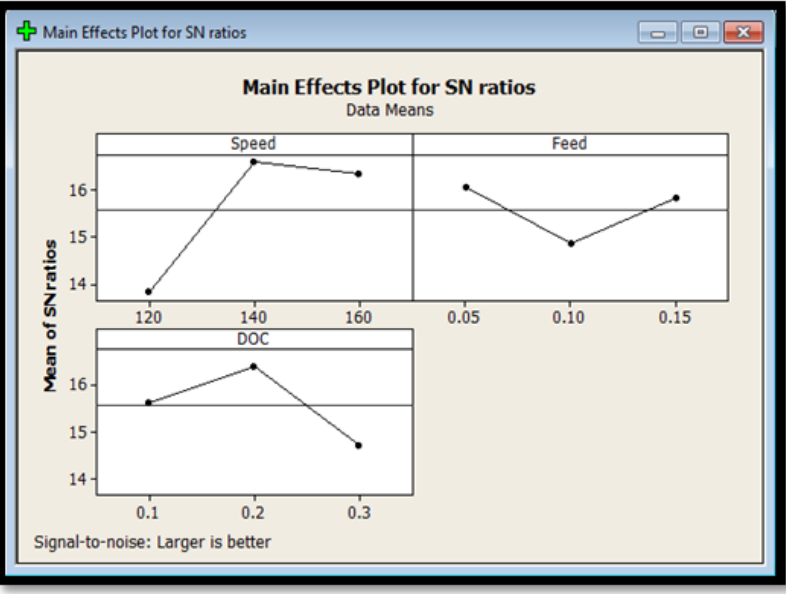

Figure 4.2: $\mathrm{S} / \mathrm{N}$ graph for Material Removal Rate

Table 6: Response for Means

\begin{tabular}{|c|c|c|c|}
\hline Level & Speed(A) & Feed(B) & DOC(C) \\
\hline 1 & 5.367 & 6.033 & 5.400 \\
\hline 2 & 6.957 & 5.440 & 6.847 \\
\hline 3 & 5.747 & 6.597 & 5.823 \\
\hline Max-min & 1.590 & 1.157 & 1.447 \\
\hline Rank & 1 & 3 & 2 \\
\hline
\end{tabular}

S/N Ratio analysis for Material Removal Rate (MRR)

Analysis of MRR versus Speed, Feed, DOC

Table 7: Response for Signal to Noise Ratios Larger is better

\begin{tabular}{|c|c|c|c|}
\hline Level & speed & feed & DOC \\
\hline 1 & 13.83 & 16.06 & 15.62 \\
\hline 2 & 16.58 & 14.86 & 16.40 \\
\hline 3 & 16.33 & 15.82 & 14.72 \\
\hline Max-min & 2.75 & 1.20 & 1.67 \\
\hline Rank & 1 & 3 & 2 \\
\hline
\end{tabular}

Table 8: Response for Means

\begin{tabular}{|c|c|c|c|}
\hline Level & Speed & Feed & DOC \\
\hline 1 & 4.923 & 6.443 & 6.073 \\
\hline 2 & 6.807 & 5.557 & 6.753 \\
\hline 3 & 6.583 & 6.313 & 5.487 \\
\hline Max-min & 1.883 & 0.887 & 1.267 \\
\hline Rank & 1 & 3 & 2 \\
\hline
\end{tabular}

\section{ANOVA results for Surface roughness (Ra)}

Table 9: ANOVA results for Surface roughness

\begin{tabular}{|c|c|c|c|c|}
\hline & $\begin{array}{c}\text { Degree of Sum of M } \\
\text { ean Percentage of } \\
\text { freedom(DF) }\end{array}$ & $\begin{array}{c}\text { Square } \\
\mathrm{s}\end{array}$ & Square & $\begin{array}{c}\text { Contribution } \\
(\%)\end{array}$ \\
\hline Speed & 2 & 4.14 & 2.07 & 43.24 \\
\hline Feed & 2 & 2.01 & 1.00 & 20.98 \\
\hline DOC & 2 & 3.32 & 1.66 & 34.70 \\
\hline Error & 2 & 0.10 & 0.052 & 1.08 \\
\hline
\end{tabular}

Table 10: ANOVA results for Material Removal Rate (MRR

\begin{tabular}{|c|c|c|c|c|}
\hline & $\begin{array}{c}\text { Degree of } \\
\text { Freedom (DF) }\end{array}$ & $\begin{array}{c}\text { Sum of } \\
\text { square S }\end{array}$ & $\begin{array}{c}\text { Mean } \\
\text { square }\end{array}$ & $\begin{array}{c}\text { Percentage of } \\
\text { contribution (\%) }\end{array}$ \\
\hline Speed & 2 & 6.35 & 3.18 & 61.98 \\
\hline Feed & 2 & 1.38 & 0.69 & 13.42 \\
\hline DOC & 2 & 2.41 & 1.21 & 23.53 \\
\hline Error & 2 & 0.11 & 0.052 & 1.07 \\
\hline
\end{tabular}

Volume 6 Issue 7, July 2017 www.ijsr.net 


\section{International Journal of Science and Research (IJSR) \\ ISSN (Online): 2319-7064}

Index Copernicus Value (2015): 78.96 | Impact Factor (2015): 6.391

\section{Conclusions}

Based on analysis of data and discussion of results, several $i$ mportant conclusions are drawn during hard turning of Vana dium steel as under.

The percentage contribution of input parameters on Surface Roughness $(\mathrm{Ra})$ is: Speed $=43.24 \%$, Feed rate $=20.98 \%$ and DOC. $=34.70 \%$, signifying the cutting speed to be the most contributing factor influencing Surface Roughness.

The percentage contribution of input parameters on Material Removal Rate $(\mathrm{MRR})$ is: Speed $=18.36 \%$, Feed rate $=$ $23.67 \%$ and DOC. $=8.74 \%$, signifying the feed rate to be the most contributing factor influencing surface roughness.

The optimized machining conditions for minimizing Surface Roughness from Taguchi analysis are approaching: cutting speed $140 \mathrm{~m} / \mathrm{min}$., feed $0.15 \mathrm{~mm} / \mathrm{rev}$., depth of cut $0.20 \mathrm{~mm}$.

The optimized machining conditions for maximizing Material Removal rate from Taguchi analysis are approaching: cutting speed $140 \mathrm{~m} / \mathrm{min}$., feed $0.05 \mathrm{~mm} / \mathrm{rev}$., depth of cut $0.2 \mathrm{~mm}$.

\section{References}

[1] Abdullah, A. (1996), "Machining of aluminium based metal matrix composite (MMC),"Ph.D. Thesis, University of Warwick, Warwick, UK, 1996.

[2] Anyilmaz M. S, (2006) "Design of Experiment and an Application for Taguchi Method in Quality Improvement Activity," M.S. Thesis, Dumlupınar University, Turkey, 2006.

[3] Armarego E.J.A. and Brown R.H. (1969), "The Machining of Metals," Prentice-Hall, Inc., 1969.

[4] Armarego, E. J. A., Verezub, S., Samaranayake, P. (2002), "The effect of coatings on the cutting process, friction, forces and predictive cutting models in machining operations," Proceedings of the Institution of Mechanical Engineers, Part B:Journal of Engineering Manufacture 216, pp.347-356,2002.

[5] Aslan E., Camus N., Bingoren B.(2007), "Design optimization of cutting parameters when turning hardened AISI 4140(63 HRC) with $\mathrm{Al} 2 \mathrm{O} 3+\mathrm{TiCN}$ mixed ceramic tool", Mater. Des. 28, pp. 1618-1622, 2007.

[6] Azman Ajri Bin. (2010), "Performance evaluation of different process conditions when hard turning ASSAB 760", 2010.

[7] Bonifacio, M. E. R., Diniz, A. E. (1994), "Correlating tool wear tool life, surface roughness and tool vibration in finish turning with coated carbide tools," Wear 173,pp.137-144,1994.

[8] Boothroyd, G. and Knight, W.A. (1989), "Fundamental Machining and Machine Tools 2nd edition," Marcel Dekker Inc. 1989.

[9] Chattopadhyay A.K., and Chattopadhyay A.B. (1982), "Wear and performance of coated carbide and ceramic tools," Vol. 80, Issue 2, pp.239-258, 1982.

[10] Cho, S. S., Komvopoulos, K. (1997), "Wear Mechanisms of Multi-Layer Coated Cemented Carbide Cutting Tools," Journal of Tribology 119, pp. 8-17,
1997. Chubb, J. P., Billingham, J. (1980), "Coated cutting tools - a study of wear mechanism in high speed machining," Wear 61, pp.283-293, 1980.

[11] Cuban jiri, Kovalkik Jaroslov. (2010), "Comparison of cutting tools inserts made of coated carbide used in turning of grey iron," Acta Technica CorviniensisBulletin of Engineering, 2010.

[12] Mihir T. Patel , Vivek A. Deshpande," Optimization of Machining Parameters for Turning Different Alloy Steel Using CNC - Review", International Journal of Innovative Research in Science, Engineering and Technology, Vol. 3, Issue 2, February 2014.

[13] Taquiuddin Quazi, Pratik gajanan," Optimization of Turning Parameters Such as Speed Rate, Feed Rate, Depth of Cut for Surface Roughness by Taguchi Method", Asian Journal of Engineering and Technology Innovation 02 (02) 2014 (05-24).

\section{Author Profile}

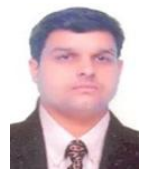

Satish Kumar joined the teaching faculty in the department of Mechanical Engineering, HCTM Technical Campus, Kaithal over 11 years back. He obtained his M.Tech from GNDEC, Ludhiana and pursuing Ph.D from MDU, Rohtak. His area of interest includes Machining and Welding. He has published over 10 research papers in reputed international journals as well as national conferences.

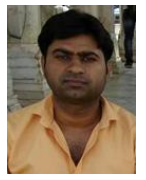

Sayed Imran received his B.Tech (Mechanical Engineering) from Haryana College of Engineering and Management, Kaithal Haryana, India. Now he is pursuing Master of Technology (Production and Industrial Engineering) in HCTM Technical Campus, Kaithal, Haryana, India. His area of interest includes Production and Manufacturing system. 